\title{
Elevated Endothelin-1 Expression in Dogs with Heartworm Disease
}

\author{
Tsuyoshi UCHIDE ${ }^{1)}$ and Kaname SAIDA ${ }^{2)}$ \\ ${ }^{1)}$ Department of Toxicology, School of Veterinary Medicine and Animal Sciences, Kitasato University, 35-1 Higashi 23-bancho, Towada, \\ Aomori 034-8628 and ${ }^{2)}$ Institute for Biological Resources and Functions, Human Stress Signal Research Center, National Institute of \\ Advanced Industrial Science and Technology (AIST), 1-1-1 Higashi, Tsukuba, Ibaraki 305-8566, Japan
}

(Received 19 April 2005/Accepted 22 July 2005)

ABSTRACT. We explored the involvement of endothelin-1 (ET-1) in the pathophysiology of dog dirofilariasis (heartworm disease caused by Dirofilaria immitis) by analyzing mRNA levels of preproendothelin-1 (PPET-1), the precursor form of ET-1, in cardiopulmonary organs as well as ET-1 peptide levels in plasma. To determine the cDNA sequence and primary protein structure of dog PPET-1, we performed molecular cloning of the full-length cDNA. Based on the determined sequence information, comparative expression analysis of PPET-1 mRNA was carried out by real-time polymerase chain reaction on cardiopulmonary organs from healthy ( $\mathrm{n}=5$ ) and filarial $(\mathrm{n}=5)$ dogs. Filarial dogs showed a significantly $(\mathrm{p}<0.05)$ higher mRNA expression level in the heart (about one hundred times) and lung (about ten times) than healthy dogs. Analysis of plasma ET-1 levels in healthy $(n=10)$ and filarial $(n=10)$ dogs showed that filarial $\operatorname{dogs}(6.9 \pm 2.7 \mathrm{pg} / \mathrm{m} l)$ have significantly $(\mathrm{p}<0.01)$ increased plasma ET-1 levels compared with healthy dogs $(1.4 \pm 0.3 \mathrm{pg} / \mathrm{m} l)$. To assess the pathophysiological significance of ET-1 in dirofilariasis relative to other cardiopulmonary disorders, plasma ET-1 levels determined in dogs diagnosed with mitral regurgitation $(n=10)$, tricuspid regurgitation $(n=5)$, ventricular septal defect $(n=5)$, and patent ductus arteriosus $(n=5)$ were compared to plasma ET-1 levels in filarial dogs. Filarial dogs, which commonly develop serious pulmonary hypertension, exhibited by far the highest ET-1 levels of the disease states examined. Based on the fact that ET-1 is a potent bioactive mediator that induces vasoconstriction and promotes vascular remodeling, these findings suggest that ET-1 plays an important role in the pathophysiology of dog dirofilariasis as an aggravating factor by inducing pulmonary hypertension.

KEY WORDS: cardiopulmonary disorder, dirofilariasis, dog endothelin-1 cDNA cloning, mRNA expression, plasma endothelin-1 level.

J. Vet. Med. Sci. 67(11): 1155-1161, 2005

Endothelin-1 (ET-1) is a bioactive peptide originally isolated from vascular endothelial cells [33]. Recent clinical studies in humans provide convincing evidence that ET-1 is intimately involved in the pathophysiology of cardiopulmonary diseases as a potent vasoconstrictor and promoter of cell proliferation. In many cardiopulmonary diseases, including pulmonary hypertension, congestive heart failure, and cardiomyopathy, the strong and prolonged pressor activity of ET-1 directly affects cardiopulmonary hemodynamics and function, and its proliferative activity causes chronic structural changes in the cardiopulmonary tissues, leading to tissue remodeling $[1,2,14]$. In patients at advanced stages of these disorders, high plasma ET-1 concentrations are often observed and are associated with the severity of the disease $[12,20,28]$.

In dogs, pulmonary hypertension is a recognized form of cardiopulmonary disease and is commonly associated with dirofilariasis (heartworm disease), which is caused by parasitic filarial nematodes (Dirofilaria immitis) residing within the animal's pulmonary artery [26]. It was believed that the pulmonary hypertension associated with dirofilariasis might be caused by embolization of the pulmonary artery due to the presence of a large number of nematodes [21, 26]. However because the severity of pulmonary hypertension does not correlate with the number of parasitic worms, it has been suggested that some unknown mediators, perhaps secreted endogenously in the pulmonary artery, produce pulmonary hypertension through vascular constriction and remodeling [7].

In this manuscript, to investigate whether ET-1 is patho- physiologically involved in dirofilariasis as an aggravating mediator that leads to pulmonary hypertension, we performed mRNA expression analysis of preproendothelin-1 (PPET-1), the precursor form of ET-1, in cardiopulmonary organs of filarial dogs in conjunction with analysis of plasma ET-1 levels.

\section{MATERIALS AND METHODS}

Samples and experimental guidelines: Tissue and blood samples used for this study were obtained under the owner's consent from dogs referred for treatment to the Kitasato University Veterinary Teaching Hospital in 2003 and 2004 because of cardiopulmonary disorders or from normal dogs kept at the University. Heart and lung tissue samples were collected from five dogs with heartworm disease (6-12 years old, 8-15 kg BW) and from five healthy, normal dogs (5-11 years old, 8-12 kg BW) for comparative analysis of mRNA expression in cardiopulmonary organs. To analyze mRNA levels systemically, liver, kidney, spleen, stomach, duodenum, colon, uterus, ovary, and testis tissues, in addition to heart and lung samples, were obtained from two filarial dogs ( 6 and 10 years old, 10 and $12 \mathrm{~kg} \mathrm{BW)} \mathrm{and} \mathrm{from} \mathrm{two}$ normal dogs ( 7 and 10 years old, 10 and $11 \mathrm{~kg} \mathrm{BW).} \mathrm{To}$ compare plasma ET-1 levels among dogs with various cardiopulmonary disorders, including mitral regurgitation (MR), tricuspid regurgitation (TR), ventricular septal defect (VSD), and patent ductus arteriosus (PDA), blood samples were collected from ten filarial dogs (6-12 years old, 7-18 
kg BW), ten MR dogs (4-12 years old, 3-11 kg BW), five TR dogs (5-12 years old, 4-14 kg BW), five VSD dogs (0.5-2 yeas old, $2-8 \mathrm{~kg} \mathrm{BW})$, and five PDA dogs $(0.5-3$ yeas old, 2-10 kg BW), as well as from ten normal dogs (111 yeas old, $8-15 \mathrm{~kg} \mathrm{BW})$. All experiments reported here were performed in accordance with the Guidelines on Handling and Care of Animals of the Committee for Animal Welfare of Kitasato University. Dirofilariasis, MR, TR, VSD, and PDA were diagnosed by physical examination, blood test, electrocardiography, and ultrasonography. Dogs that appeared to have symptoms of inflammatory disease, which could affect plasma ET-1 level, were excluded in this study based on a blood test.

Preparation of total RNA and mRNA: Dog tissue samples obtained from healthy and diseased dogs were preserved at $-80^{\circ} \mathrm{C}$ immediately after freezing in liquid nitrogen. Total RNA was prepared from tissue homogenate using Isogen solution (Nippon Gene, Japan) according to the manufacturer's protocol. For cDNA cloning, mRNA was obtained from lung total RNA by oligo (dT)-cellulose chromatography (Amersham Pharmacia Biotech, UK).

Full-length cDNA cloning: Lung tissue used for cDNA cloning was obtained from a normal male dog (8 yeas old, $10 \mathrm{~kg} \mathrm{BW}$ ). First-strand cDNA was synthesized with mRNA from dog lung tissue using avian myeloblastosis virus (AMV) reverse transcriptase (TaKaRa, Japan). The oligonucleotide primers (DET-1/F and DET-1/R) used to amplify a portion of the middle region of dog PPET-1 cDNA were designed based on the nucleotide sequences conserved among humans [9], mice [16], rats [24], and pigs [33] (Table 1). Using these primers, polymerase chain reaction (PCR) was performed with AmpliTaq Gold DNA polymerase (Applied Biosystems, U.S.A.) under the following conditions: 1 cycle of $95^{\circ} \mathrm{C}$ for $10 \mathrm{~min} ; 35$ cycles of $95^{\circ} \mathrm{C}$ for $1 \mathrm{~min}, 60^{\circ} \mathrm{C}$ for $1 \mathrm{~min}$, and $72^{\circ} \mathrm{C}$ for $3 \mathrm{~min}$; and 1 cycle of $72^{\circ} \mathrm{C}$ for $30 \mathrm{sec}$. To clone the 5'- and 3'-cDNA ends of dog PPET-1, RT-PCR in combination with 5'- and 3'-rapid amplification of cDNA ends (RACE) was performed using a commercially available kit (SMART ${ }^{\mathrm{TM}}$ RACE cDNA Amplification Kit, Clontech, U.S.A.). The first-strand
cDNA was synthesized with Moloney murine leukemia virus (MMLV) reverse transcriptase (Clontech, U.S.A.) according to the manufacturer's protocol. For amplification of first-strand cDNA, gene specific (GS) primers and nested gene specific (NGS) primers were designed to produce an overlapping region between the middle partial cDNA and 5'- or 3'-RACE-PCR fragments (Table 1). The following conditions were used to perform 5'-RACE PCR with 5'GSP or 5'-NGSP using AmpliTaq Gold DNA polymerase (Applied Biosystems, U.S.A.): 1 cycle of $95^{\circ} \mathrm{C}$ for $10 \mathrm{~min}$; 35 cycles of $95^{\circ} \mathrm{C}$ for $1 \mathrm{~min}, 65^{\circ} \mathrm{C}$ for $1 \mathrm{~min}$ and $72^{\circ} \mathrm{C}$ for 3 min; and 1 cycle of $72^{\circ} \mathrm{C}$ for $30 \mathrm{sec}$. The same conditions were used for 3'-RACE PCR with 3'-GSP or 3'-NGSP as for 5'-RACE PCR. After agarose gel electrophoresis of the PCR products, a fragment of the predicted size was purified from the gel and inserted into a plasmid vector, pCR2.1 (Invitrogen, U.S.A.).

DNA sequencing: DNA sequencing was performed on both strands using the ABI PRISM BigDye Terminator Cycle Sequencing Ready Reaction Kit (Applied Biosystems, U.S.A.) with an automated DNA sequence analyzer (Model 310, Applied Biosystems, U.S.A.). To avoid possible sequencing errors due to RACE artifacts, the sequence analysis was performed on 20 independent clones derived from each RCR. The full-length cDNA sequence was obtained by combining the overlapping regions between the middle cDNA portion and the 5' or 3' ends. The complete nucleotide and deduced amino acid sequences were analyzed by commercial software (GENETYX-MAC Ver.10, Software Development, Japan).

Conventional PCR: Oligonucleotide primers specific for dog PPET-1 cDNA (PPET-1/F and PPET-1/R) were designed based on the full-length cDNA sequence obtained by cloning (Table 1 and Fig. 1). Primers specific for the glyceraldehyde-3-phosphate dehydrogenase gene (GAPDH/ $\mathrm{F}$ and GAPDH/R), which is known as a housekeeping gene, were also designed (Table 1). cDNAs were synthesized with AMV reverse transcriptase (TaKaRa, Japan) from total RNAs obtained from dog tissues. PCR was performed with AmpliTaq Gold DNA polymerase (Applied Biosystems,

Table 1. Primers used for cloning and cDNA amplification of dog PPET-1 and GAPDH

\begin{tabular}{llll}
\hline \multicolumn{1}{c}{ Name } & \multicolumn{1}{c}{ Nucleotide sequence } & & Used for \\
\hline DET-1/F & 5'-TCCAAGGAGCTCCAGAA-3' & (Sense) & cDNA cloning \\
DET-1/R & 5'-AAATACATAGACCAATATGGC-3' & (Antisense) & cDNA cloning \\
5'-GS & 5'-CTGTTCCTGTGGTCTGTCGCCTTC-3' & (Antisense) & cDNA cloning \\
3'-GS & 5'-AGCTCAGCACAGGCCCGGAC-3' & (Sense) & cDNA cloning \\
5'-NGS & 5'-AACAGGGAAGAGCAGGAGCAG-3' & (Antisense) & cDNA cloning \\
3'-NGS & 5'-CCAAGGAGCTCCAGAAGCAGCAGTC-3' & (Sense) & cDNA cloning \\
\hline PPET-1/F & 5'-TCTTCCCTGATGGATAAAGAGTG-3' & (Sense) & Conventional PCR \\
PPET-1/R & 5'-AAGCTGTTTTGATGCTGTTGC-3' & (Antisense) & Conventional PCR \\
GAPDH/F & 5'-CTTCACCACCATGGAGAAGGC-3' & (Sense) & Conventional PCR \\
GAPDH/R & 5'-CTCATGACCACAGTCCATGCCA-3' & (Antisense) & Conventional PCR \\
\hline PPET-1/rF & 5'-GGACAGCAGGGGGGAGAA-3' & (Sense) & Real-time PCR \\
PPET-1/rR & 5'-GTTGACCCAGATGATGTCAAGGT-3' & (Antisense) & Real-time PCR \\
TaqMan probe & 5'-FAM-TCCAAGCGCTGCTCCTGCTCTTCC-TAMRA-3' & Real-time PCR \\
\hline
\end{tabular}




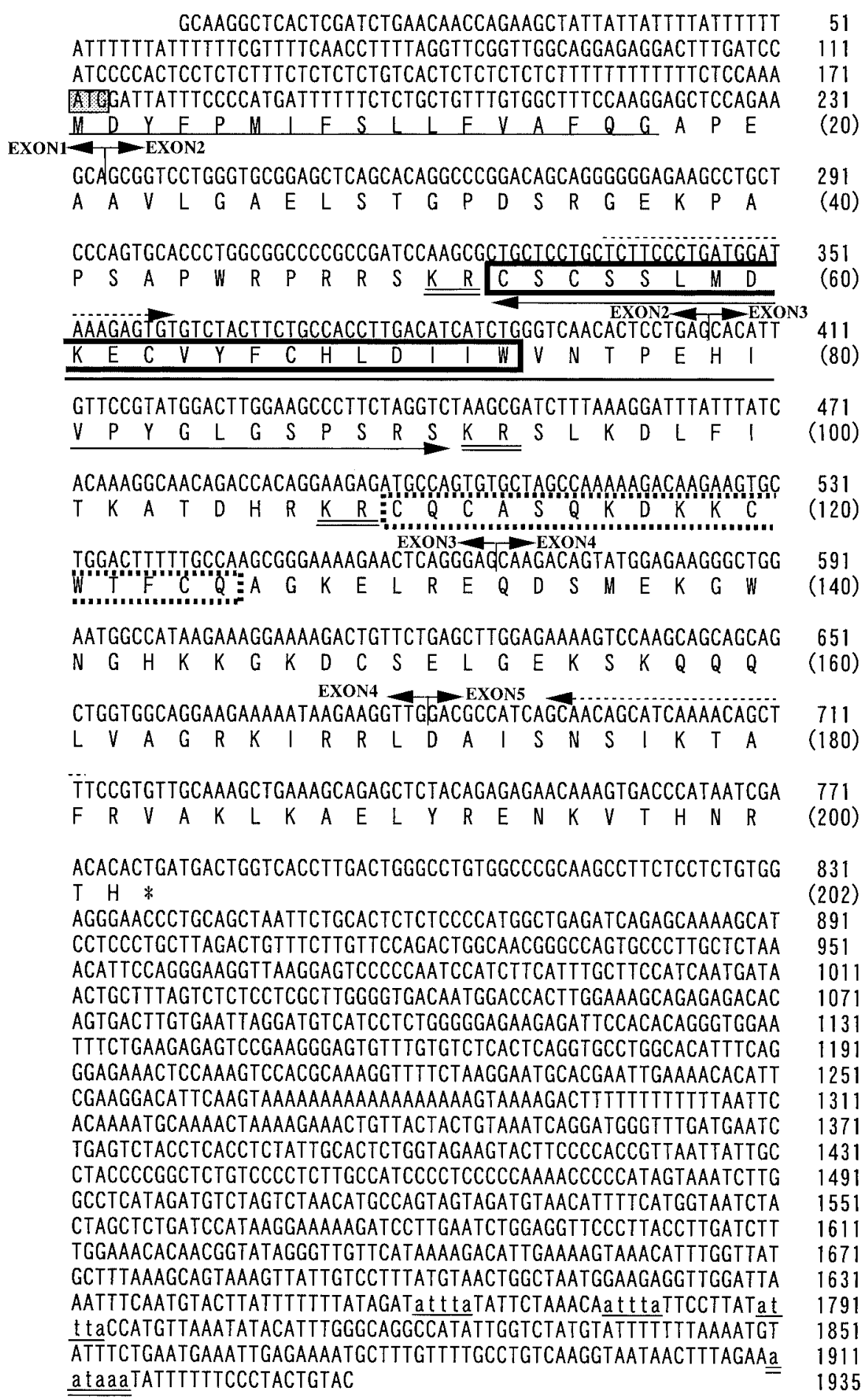

Fig. 1. Nucleotide and deduced amino acid sequences of dog PPET-1. The full-length dog PPET-1 cDNA is 1935 bp, excluding the poly (A) tail. A 606-nucleotide open reading frame encoding 202 amino acids of dog PPET-1 follows the ATG codon closest to the 5' end shown by the shaded box. The stop codon is indicated by an asterisk. The amino acid sequence denoted by an underline indicates the putative signal peptide. Endothelin mature, big, and like peptides are indicated by a box, double-headed arrow, and dashed box, respectively. Dibasic amino acid pairs, which are recognized by processing endopeptidase, are double-underlined. The consensus sequences of mRNA instability and the polyadenylation signal in the 3' non-coding region are indicated by lowercase letters that are underlined and double-underlined, respectively. Primer pairs used for analysis of organ distribution of transcripts (Fig. 2) are indicated by dashedline arrows. A putative exon organization is shown, as predicted based on the human PPET-1 gene structure. Amino acid and nucleotide sequences are numbered on the right with and without parentheses, respectively. 
U.S.A.) under the following conditions: 1 cycle of $95^{\circ} \mathrm{C}$ for 10 min; 35 (PPET-1) or 25 (GAPDH) cycles of $95^{\circ} \mathrm{C}$ for 1 min, $65^{\circ} \mathrm{C}$ for $2 \mathrm{~min}$ and $72^{\circ} \mathrm{C}$ for $3 \mathrm{~min}$; and 1 cycle of $72^{\circ} \mathrm{C}$ for $30 \mathrm{sec}$.

Real-time PCR: Quantitative analysis of dog PPET-1 mRNA was performed by real-time PCR as described in previous reports $[29,30]$. Briefly, oligonucleotide primers (PPET-1/rF and PPET-1/rR) and a detection probe (TaqMan Probe, Applied Biosystems, U.S.A.) were designed (Table 1). Dog PPET-1 cDNA inserted in plasmid was prepared as a quantitative standard for estimating PPET-1 mRNA levels. Amplification was carried out with a TaqMan PCR kit (Applied Biosystems, U.S.A.). Template was mixed with 1 $\times$ buffer, $3.5 \mathrm{mM} \mathrm{MgCl} 2,200 \mu \mathrm{M}$ dATP, $200 \mu \mathrm{M} \mathrm{dCTP}$, $200 \mu \mathrm{M}$ dGTP, $400 \mu \mathrm{M}$ dUTP, $0.025 \mathrm{U} / \mu l$ AmpliTaq Gold polymerase, $100 \mathrm{nM}$ TaqMan Probe, and $200 \mathrm{nM}$ of each primer. All reactions were performed in a Model 7700 Sequence Detector (Applied Biosystems, U.S.A.). Reaction conditions were $95^{\circ} \mathrm{C}$ for $10 \mathrm{~min}$ followed by 50 cycles of the amplification step $\left(95^{\circ} \mathrm{C}\right.$ for $15 \mathrm{sec}$ and $60^{\circ} \mathrm{C}$ for $\left.1 \mathrm{~min}\right)$. To quantify the amount of PPET-1 mRNA, standard curves were determined with ten-fold serially diluted standard templates by plotting the starting amount of the standard templates against the number of threshold cycles. The $18 \mathrm{~S}$ ribosomal RNA level, assessed by a commercial kit (TaqMan Ribosomal RNA Control Reagents Kit, Applied Biosystems, U.S.A.), was used as an internal control to normalize PPET-1 mRNA levels. The relative gene expression level was calculated using the formula: (ET-1 mRNA level / GAPDH mRNA level) $\times 100$.

Plasma ET-1 levels: Blood samples collected in EDTA tubes were centrifuged at $1,600 \times \mathrm{g}$ for $15 \mathrm{~min}$ at $4^{\circ} \mathrm{C}$. The plasma was stored at $-80^{\circ} \mathrm{C}$ until use. After ET-containing fractions were obtained through a C18 Sep-Pak column (Waters, U.S.A.), the ET-1 concentration in each of the fractions was measured using an enzyme immunometric assay (EIA) system with anti-ET-1 rabbit antibody (ET-1 EIA Kit, IBL, Japan) according to the manufacturer's protocol. The plasma ET-1 concentration was calculated based on the ET1 level in each of the fractions. The assay for ET-1 did not cross-react with ET-2, ET-3, big ET-1, big ET-2, or big ET3 (cross-reactivity $<0.1 \%$ ).

Statistical analysis: The Mann-Whitney Test was used for analysis of significant differences among the data.

\section{RESULTS}

Full-length cDNA sequence and primary protein structure of PPET-1: The full-length cDNA sequence of dog PPET-1 was determined by combining the sequence information from the partial 5'- and 3'-RACE PCR clones. Figure 1 shows the nucleotide and deduced amino acid sequences. Aside from the poly (A) tail, the full-length dog PPET- 1 cDNA is 1935 bp. The ATG and TGA triplets corresponding to the predicted initiation and stop codons are located at 172-174 and 778-780, respectively. The cDNA has a 606-bp open reading frame (ORF) encoding a 202- amino acid polypeptide. The N-terminal 17 amino acids of PPET-1 are considered to be the signal peptide, which can be predicted by the method of von Heijne [32]. In the 3'untranslated region (UTR), the consensus polyadenylation signal AATAAA [23] is observed at position 1911-1916. Three copies of the consensus sequence, ATTTA, are present at positions $1661-1665,1677-1681$, and 1790 1794. This motif, which also is found in human PPET-1 cDNA [10], is proposed to mediate selective translationdependent destabilization of mRNA, as was demonstrated for cytokine genes $[5,8,13]$. Structural analysis of the deduced prepropolypeptide demonstrates that regions corresponding to a bioactive mature ET-1 peptide $\left(\mathrm{C}^{53}-\mathrm{W}^{73}\right)$, an intermediate form big ET-1 $\left(\mathrm{C}^{53}-\mathrm{S}^{91}\right)$, and an endothelinlike (ET-like) peptide $\left(\mathrm{C}^{110}-\mathrm{Q}^{125}\right)$ are found on the deduced polypeptide, as they are in other mammals including humans [9], mice [16], rats [24], and pigs [33]. The dog big ET-1 is flanked by dibasic amino acid pairs, which are recognized by processing endopeptidases, at both the $\mathrm{N}$ - and $\mathrm{C}$ terminals $\left(\mathrm{K}^{51}-\mathrm{R}^{52}\right.$ and $\left.\mathrm{K}^{92}-\mathrm{R}^{93}\right)$. The ET-like peptide within PPET-1 is structurally related to the N-terminal 16 amino acids of mature ET-1 and shares eight amino acids with ET-1, including four cysteine residues, which is consistent with results for other mammals. Comparative analysis shows that the similarity of the dog ORF sequence with those of humans, mice, rats, and pigs is 78.6, 79.6, 80.8, and $86.1 \%$ and that the similarity at the amino acid level is 70.3 , $75.7,75.2$, and $80.3 \%$, respectively. The sequence data have been deposited with the EMBL/GenBank/DDBJ Data Libraries under Accession No. AB115087.

Analysis of dog PPET-1 transcripts in various organs: Organ distribution of PPET-1 mRNA, as well as any potential splicing variant, was analyzed by conventional PCR. Figure 2 shows the expression of PPET-1 and GAPDH mRNAs. PPET-1 gene expression was detected in all the organs surveyed, including the heart, lung, liver, kidney, spleen, stomach, duodenum, colon, uterus, ovary, and testis. The primers for this experiment were designed to span introns 2, 3, and 4 to generate a 376-bp fragment (Fig. 1) based on our cDNA sequence and the human PPET-1 gene structure [10]. No other expected band was observed in any of the organs studied, indicating the absence of splicing variants, which were observed in human PPET-2 mRNA [22]. Subsequently, we confirmed, through cloning and sequencing, that the PCR fragments are those from dog PPET-1 cDNA (Data not shown.).

Quantitative analysis of dog PPET-1 mRNA levels in various organs: To quantitatively analyze dog PPET-1 mRNA levels, we established an assay system based on real-time PCR, designing specific primer pairs and a TaqMan probe (Table 1). Comparative quantitative analysis of mRNA expression in organs between healthy and filarial dogs was performed. The average data for two dogs from each group are compared in Fig. 3-A. In healthy dogs, PPET-1 gene expression was detected in all organs, including the heart, lung, liver, kidney, spleen, stomach, duodenum, colon, uterus, ovary, and testis, with an especially high level 


\section{PPET-1}

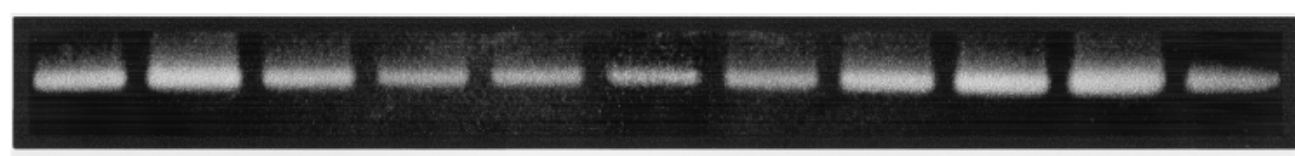

GAPDH

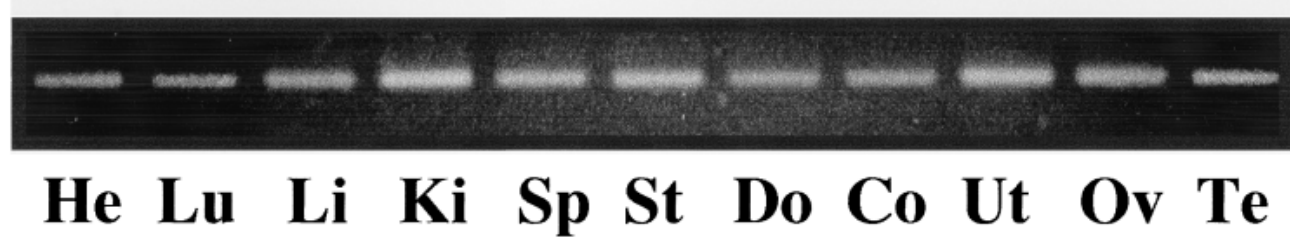

Fig. 2. Organ distribution of dog PPET-1 mRNA. Total RNA was prepared from the heart (He), lung (Lu), liver (Li), kidney (Ki),spleen (Sp), stomach (St), duodenum (Do), colon (Co), ovary (Ov), uterus (Ut), and testis (Te). After the RT reaction, the organ distribution of dog PPET-1 mRNA was examined by conventional PCR. GAPDH cDNA was amplified as an internal control.

observed in the lung. The gene expression level found in the lung was roughly 10 to 100 times higher than that found in any other organ. The expression pattern in dogs, in which dominant expression occurs in the lung, with a relatively high level of expression in the ovary and uterus, mirrors the PPET-1 gene expression pattern observed in mice [31]. In filarial dogs, PPET-1 gene expression levels were markedly increased in the heart and lung compared with healthy controls. For statistical analysis, we examined the PPET-1 expression levels in the heart and lung of five filarial dogs and five healthy controls (Fig. 3-B). In the hearts of filarial dogs, the PPET-1 gene expression level was significantly $(p<0.05)$ higher, about 100 times greater than in healthy controls. In the lungs of filarial dogs, the PPET-1 gene expression level was also significantly $(p<0.05)$ higher, about ten times greater than in healthy controls.

Plasma ET-1 levels: Plasma ET-1 concentrations in ten healthy controls and ten filarial dogs were measured using an ET-1 EIA kit (Fig. 4). The plasma ET-1 levels in filarial dogs $(6.9 \pm 2.7 \mathrm{pg} / \mathrm{m} l)$ were significantly $(\mathrm{p}<0.01)$ increased compared with healthy dogs $(1.4 \pm 0.3 \mathrm{pg} / \mathrm{m} l)$. To assess the pathophysiological significance of ET-1 in dirofilariasis relative to other cardiopulmonary disorders, plasma ET-1 levels were measured in dogs diagnosed with MR, TR, VSD, or PDA and were compared with levels measured in dogs diagnosed with dirofilariasis (Table 2). Of all the diseased dogs examined, filarial dogs showed the highest ET-1 levels.

\section{DISCUSSION}

Histopathological changes, including detachment of pulmonary vascular endothelial cells and thickening of the pulmonary artery wall, have been demonstrated in filarial dogs $[21,27]$. Pulmonary vascular structural changes cause a progressive rise in pulmonary arterial pressure (pulmonary hypertension) and consequently lead to the development of right ventricular hypertrophy in dirofilariasis [25]. Thus, vascular remodeling is an important factor in determining the pathophysiological progression of filariasis. ET-1, which shows markedly increased plasma levels in filarial dogs, is a biphasic biological mediator that induces acute vasoconstriction and chronic vascular remodeling [4]. It is probable that the chronic remodeling and acute vasoconstrictive activities work synergistically in the development of pulmonary hypertension. The observation of markedly up-regulated PPET-1 gene expression limited to the hearts and lungs of filarial dogs suggests that the cardiopulmonary system is a major source of ET-1 production in dirofilariasis. Studies done over the past decade have demonstrated that PPET-1 mRNA expression is induced in vascular endothelial cells and cardiac tissue by various cytokines [17, 18], hypoxia [15], and shear stress [34]. Therefore, it is reasonable to conclude that the increased mRNA expression in filarial cardiopulmonary organs results from cytokine production triggered by an immunological reaction to the nematodes residing within the pulmonary arteries and heart, hypoxia resulting from filarial embolization within the pulmonary arteries, and physical stress to the surrounding tissues caused by the nematodes themselves.

In human medicine, various cardiopulmonary disorders accompanied by elevated plasma ET-1 levels have been reported, including cardiac valvular disease, myocardial infarction, and congenital heart diseases $[11,12,19]$. In these patients, ET-1 levels correlate strongly with pulmonary artery pressure and pulmonary vascular resistance, and thus with the severity of secondary pulmonary hypertension [6]. Taking these findings in humans into consideration, we assessed plasma ET-1 levels in dog congenital or degenerative valvular cardiopulmonary disorders such as MR, TR, VSD, and PDA to compare the pathophysiological significance of ET-1 and perhaps the severity of the pulmonary hypertension in these diseases with its significance in dirofilariasis. Detection of higher plasma ET-1 levels in filarial dogs than in dogs with the other diseases explains why dirofilariasis, of all the disorders, most commonly leads to severe pulmonary hypertension.

In human clinical research, a treatment strategy for cardiopulmonary disorders using endothelin receptor antagonists has been proven to greatly improve the survival rate by preventing harmful vascular and cardiac remodeling [3]. A detailed clinical study of the efficacy of an endothelin receptor antagonist as a potential therapeutic agent for dog dirofilariasis is anticipated in veterinary medicine. 


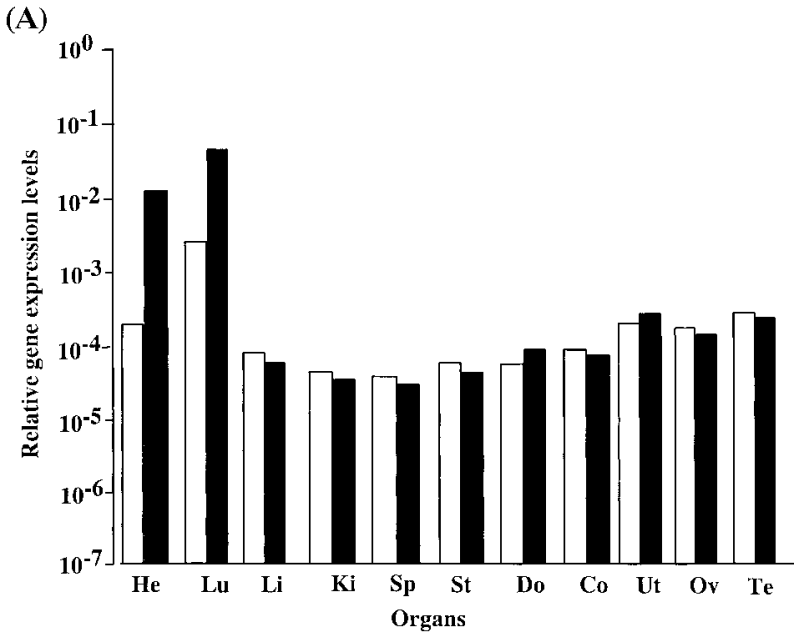

(B)

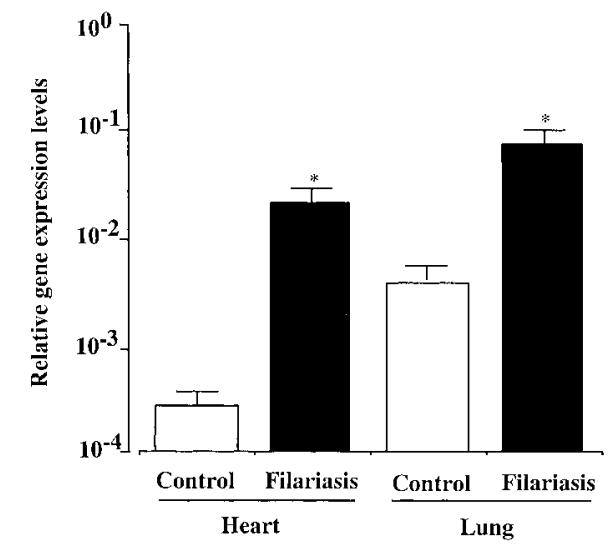

Fig. 3. (A) Quantitative analysis of the PPET-1 mRNA levels in organs. PPET-1 gene expression levels in the heart (He), lung $(\mathrm{Lu})$, liver (Li), kidney (Ki), spleen (Sp), stomach (St), duodenum (Do), colon (Co), ovary (Ov), uterus (Ut), and testis (Te), quantitatively analyzed by real-time PCR in two healthy controls (white bars) and two filarial dogs (black bars), are shown as average values. (B) Comparative analysis of PPET-1 mRNA levels in the heart and lung. PPET-1 gene expression levels in the heart and lung were analyzed by real-time PCR in five healthy controls (white bars) and five filarial dogs (black bars). The results are shown as means \pm SD. Expression levels in the filarial dogs are significantly $(*: p<0.05)$ higher than those in the healthy controls.

Table 2. Plasma ET-1 levels in various cardiopulmonary disorders

\begin{tabular}{ccc}
\hline Diagnosis & Number of dogs & Plasma ET-1 $(\mathrm{pg} / \mathrm{ml})$ \\
\hline Dirofilariasis & 10 & $6.9 \pm 2.7^{*}$ \\
MR & 10 & $4.9 \pm 2.3$ \\
TR & 5 & $3.6 \pm 0.7$ \\
VSD & 5 & $4.1 \pm 1.5$ \\
PDA & 5 & $2.6 \pm 1.0$ \\
\hline Control & 10 & $1.4 \pm 0.3$ \\
\hline
\end{tabular}

MR: mitral regurgitation, TR: tricuspid regurgitation, VSD: ventricular septal defect, and PDA: patent ductus arteriosus. Shown as mean $\pm \mathrm{SD}, *$ : significantly high with $\mathrm{p}<0.05$ versus $M R$, TR, and VSD or with $\mathrm{p}<0.01$ versus PDA and control.

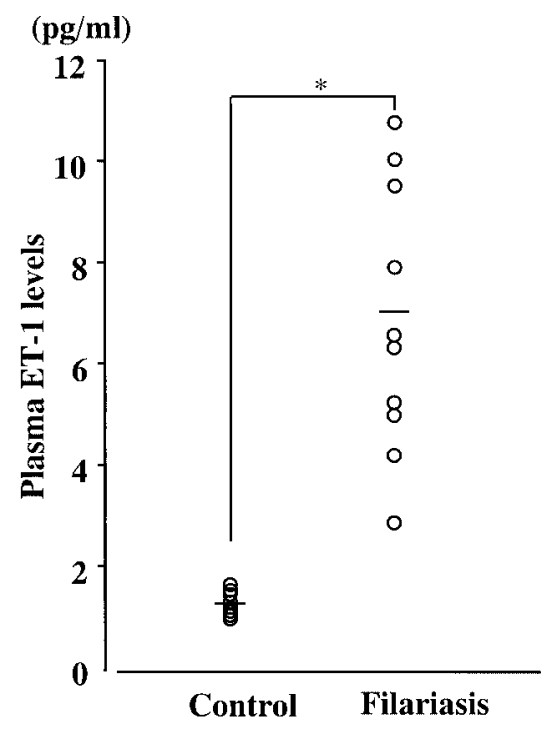

Fig. 4. Plasma ET-1 levels in healthy and filarial dogs. Plasma ET-1 levels were measured in ten healthy controls and in ten filarial dogs. Each point represents an individual plasma ET-1 value. The horizontal lines represent the means for each group. Plasma ET-1 levels in filarial dogs are significantly $(*: \mathrm{p}<0.01)$ higher than those in healthy controls.

ACKNOWLEDGMENTS. The authors gratefully acknowledge Dr. Masami Uechi for supplying precious blood samples and also thank members of our laboratory, Dr. Kyousuke Temma and Dr. Takushi Sasaki, for discussion of this work. This work was supported by a Grant for Scientific Research (No.S0501) from the School of Veterinary Medicine and Animal Sciences, Kitasato University, and by a Grant-in-Aid for Scientific Research (No. 17580271) from the Japan Society for the Promotion of Science (JSPS).

\section{REFERENCES}

1. Cannan, C.R., Burnett, J.C. Jr. and Lerman, A. 1996. Enhanced coronary vasoconstriction to endothelin-B-receptor activation in experimental congestive heart failure. Circulation 93: 646651.

2 Cannan, C.R., Mathew, V. and Lerman, A. 1998. New insight into coronary endothelial dysfunction: role of endothelin. $J$. Lab. Clin. Med. 131: 300-305.

3 Channick, R.N., Simonneau, G., Sitbon, O., Robbins, I.M., Frost, A., Tapson, V.F., Badesch, D.B., Roux, S., Rainisio, M., Bodin, F. and Rubin, L.J. 2001. Effects of the dual endothelinreceptor antagonist bosentan in patients with pulmonary hypertension: a randomised placebo-controlled study. Lancet $\mathbf{3 5 8}$ : 1119-1123.

4 Chen, Y.F. and Oparil, S. 2000. Endothelin and pulmonary hypertension. J. Cardiovasc. Pharmacol. 35: S49-53.

5 Chesney, J., Mitchell, R., Benigni, F., Bacher, M., Spiegel, L., Al-Abed, Y., Han, J.H., Metz, C. and Bucala, R. 1999. An inducible gene product for 6-phosphofructo-2 kinase with an AU-rich instability element: role in tumor cell glycolysis and 
the Warburg effect. Proc. Natl. Acad. Sci. U.S.A. 96: 30473052.

6 Cody, R.J., Haas, G.J., Binkley, P.F., Capers, Q. and Kelley, R. 1992. Plasma endothelin correlates with the extent of pulmonary hypertension in patients with chronic congestive heart failure. Circulation 85: 504-509.

7 Dillon, R. A., Brawner, W. R. and Hanrahan, L. 1995. Influence of number of parasites and exercise on the severity of heartworm disease in dogs. pp. 113. In: Proceedings of The Heartworm Symposium '95. American Heartworm Society, Vatavia.

8 Gueydan, C., Droogmans, L., Chalon, P., Huez, G., Caput, D. and Kruys, V. 1999. Identification of TIAR as a protein binding to the translational regulatory AU-rich element of tumor necrosis factor alpha mRNA. J. Biol. Chem. 274: 2322-2326.

9 Inoue, A., Yanagisawa, M., Kimura, S., Kasuya, Y., Miyauchi, T., Goto, K. and Masaki, T. 1989. The human endothelin family: three structurally and pharmacologically distinct isopeptides predicted by three separate genes. Proc. Natl. Acad. Sci. U.S.A. 86: $2863-2867$.

10 Inoue, A., Yanagisawa, M., Takuwa, Y., Mitsui, Y., Kobayashi, M. and Masaki, T. 1989. The human preproendothelin-1 gene. Complete nucleotide sequence and regulation of expression. J. Biol. Chem. 264: 14954-14959.

11 Ishikawa, S., Miyauchi, T., Sakai, S., Sunagawa, H., Honda, S., Maeda, S., Matsuda, M., Yamaguchi, I., Goto, K. and Sugishita, Y. 1995. Plasma endothelin-1 levels after exercise in patients with congenital heart disease. J. Cardiovasc. Pharmacol. 26: S491-493.

12 Ishikawa, S., Miyauchi, T., Sakai, S., Ushinohama, H., Sagawa, K., Fusazaki, N., Kado, H., Sunagawa, H., Honda, S. and Ueno, H. 1995. Elevated levels of plasma endothelin-1 in young patients with pulmonary hypertension caused by congenital heart disease are decreased after successful surgical repair. J. Thorac. Cardiovasc. Surg. 110: 271-273.

13 Jarrousse, A.S., Petit, F., Kreutzer-Schmid, C., Gaedigk, R. and Schmid, H.P. 1999. Possible involvement of proteasomes (prosomes) in AUUUA-mediated mRNA decay. J. Biol. Chem. 274: 5925-5930.

14 Kiowski, W., Sutsch, G., Hunziker, P., Muller, P., Kim, J., Oechslin, E., Schmitt, R., Jones, R. and Bertel, O. 1995. Evidence for endothelin-1-mediated vasoconstriction in severe chronic heart failure. Lancet 346: 732-736.

15 Kourembanas, S., Marsden, P.A., McQuillan, L.P. and Faller, D.V. 1991. Hypoxia induces endothelin gene expression and secretion in cultured human endothelium. J. Clin. Invest. 88: 1054-1057.

16 Kurama, M., Ishida, N., Matsui, M., Saida, K. and Mitsui, Y. 1996. Sequence and neuronal expression of mouse endothelin1 cDNA. Biochim. Biophys. Acta. 1307: 249-253.

17 Kurihara, H., Yoshizumi, M., Sugiyama, T., Takaku, F., Yanagisawa, M., Masaki, T., Hamaoki, M., Kato, H. and Yazaki, Y. 1989. Transforming growth factor-beta stimulates the expression of endothelin mRNA by vascular endothelial cells. Biochem. Biophys. Res. Commun. 159: 1435-1440.

18 Lamas, S., Michel, T., Collins, T., Brenner, B.M. and Marsden, P.A. 1992. Effects of interferon-gamma on nitric oxide synthase activity and endothelin-1 production by vascular endothelial cells. J. Clin. Invest. 90: 879-887.

19 Miyauchi, T., Yanagisawa, M., Tomizawa, T., Sugishita, Y., Suzuki, N., Fujino, M., Ajisaka, R., Goto, K. and Masaki, T. 1989. Increased plasma concentrations of endothelin-1 and big endothelin-1 in acute myocardial infarction. Lancet 8653: 53-
54.

20 Miyauchi, T., Yorikane, R., Sakai, S., Sakurai, T., Okada, M., Nishikibe, M., Yano, M., Yamaguchi, I., Sugishita, Y. and Goto, K. 1993. Contribution of endogenous endothelin-1 to the progression of cardiopulmonary alterations in rats with monocrotaline-induced pulmonary hypertension. Circ. Res. 73: 887897.

21 Munnell, J.F., Weldon, J.S., Lewis, R.E., Thrall, D.E. and McCall, J.W. 1980. Intimal lesions of the pulmonary artery in dogs with experimental dirofilariasis. Am. J. Vet. Res. 41: $1108-1112$.

22 O'Reilly, G., Charnock-Jones, D.S., Morrison, J.J., Cameron, I.T., Davenport, A.P. and Smith, S.K. 1993. Alternatively spliced mRNAs for human endothelin-2 and their tissue distribution. Biochem. Biophys. Res. Commun. 193: 834-840.

23 Proudfoot, N.J. and Brownlee, G.G. 1976. 3' non-coding region sequences in eukaryotic messenger RNA. Nature (Lond.) 263: 211-214.

24 Sakurai, T., Yanagisawa, M., Inoue, A., Ryan, U.S., Kimura, S., Mitsui, Y., Goto, K. and Masaki, T. 1991. cDNA cloning, sequence analysis and tissue distribution of rat preproendothelin-1 mRNA. Biochem. Biophys. Res. Commun. 175: 44-47.

25 Sasaki, Y., Kitagawa, H. and Hirano, Y. 1992. Relationship between pulmonary arterial pressure and lesions in the pulmonary arteries and parenchyma, and cardiac valves in canine dirofilariasis. J. Vet. Med. Sci. 54: 739-744.

26 Schaub, R.G. and Rawlings, C.A. 1980. Pulmonary vascular response during phases of canine heartworm disease: scanning electron microscopic study. Am. J. Vet. Res. 41: 1082-1089.

27 Schaub, R.G., Rawlings, C.A. and Keith, J.C. Jr. 1981. Platelet adhesion and myointimal proliferation in canine pulmonary arteries. Am. J. Pathol. 104: 13-22.

28 Stewart, D.J., Levy, R.D., Cernacek, P. and Langleben, D. 1991. Increased plasma endothelin-1 in pulmonary hypertension: marker or mediator of disease? Ann. Intern. Med. 114: 464-469.

29 Uchide, T., Adur, J., Fukamachi, T. and Saida, K. 2000. Quantitative analysis of endothelin- 1 and vasoactive intestinal contractor/endothelin-2 gene expression in rats by real-time reverse transcriptase polymerase chain reaction. $J$. Cardiovasc. Pharmacol. 36: S5-8.

30 Uchide, T., Adur, J. and Saida, K. 2001. Rapid quantification of murine endothelin-1 and vasoactive intestinal contractor gene expression levels by a real-time PCR system. J. Biotechnol. 84: $187-192$.

31 Uchide, T., Masuda, H., Mitsui, Y. and Saida, K. 1999. Gene expression of vasoactive intestinal contractor/endothelin-2 in ovary, uterus and embryo: comprehensive gene expression profiles of the endothelin ligand-receptor system revealed by semi-quantitative reverse transcription-polymerase chain reaction analysis in adult mouse tissues and during late embryonic development. J. Mol. Endocrinol. 22: 161-171.

32 von Heijne, G. 1986. A new method for predicting signal sequence cleavage sites. Nucleic. Acids. Res. 14: 4683-4690.

33 Yanagisawa, M., Kurihara, H., Kimura, S., Tomobe, Y., Kobayashi, M., Mitsui, Y., Yazaki, Y., Goto, K. and Masaki T. 1988. A novel potent vasoconstrictor peptide produced by vascular endothelial cells. Nature (Lond.) 332: 411-415.

34 Yoshizumi, M., Kurihara, H., Sugiyama, T., Takaku, F., Yanagisawa, M., Masaki, T. and Yazaki, Y. 1989. Hemodynamic shear stress stimulates endothelin production by cultured endothelial cells. Biochem. Biophys. Res. Commun. 161: 859-864. 